Popovych Igor, Mysula Igor, Popovych Andriy, Mysula Yuriy, Sydliaruk Nataliya, Bilas Volodymyra, Zukow Walery. Role of organic carbon and nitrogen of mineral waters in their immunomodulating effects at female rats. Journal of Education, Health and Sport. 2021;11(9):886-894. eISSN 2391-8306. DOI http://dx.doi.org/10.12775/JEHS.2021.11.09.104 https://apcz.umk.pl/czasopisma/index.php/JEHS/article/view/JEHS.2021.11.09.104 https://zenodo.org/record/5856299

\author{
The journal has had 5 points in Ministry of Science and Higher Education parametric evaluation. \& 8. 2) and § 12.1. 2) 22.02.2019. \\ (c) The Authors 2021; \\ This article is published with open access at Licensee Open Journal Systems of Nicolaus Copernicus University in Torun, PolandOpen Access. This article is distributed under the \\ terms of the Creative Commons Attribution Noncommercial License which permits any noncommercial use, distribution, and reproduction in any medium,provided the original \\ author (s) and source are credited. This is an open access article licensed under the terms of the Creative Commons Attribution Non commercial license Share \\ alike.(http://creativecommons.org/licenses/by-nc-sa/4.0/) which permits unrestricted, non commercial use, distribution and reproduction in any medium, provided the work is properly \\ cited.The authors declare that there is no conflict of interests regarding the publication of this paper. \\ Received: 10.09.2021. Revised: 20.09.2021. Accepted: 30.09.2021.
}

\title{
ROLE OF ORGANIC CARBON AND NITROGEN OF MINERAL WATERS IN THEIR IMMUNOMODULATING EFFECTS AT FEMALE RATS
}

\author{
Igor Popovych $^{1}$, Igor Mysula ${ }^{2}$, Andriy Popovych ${ }^{1}$, Yuriy Mysula ${ }^{2}$, Nataliya Sydliaruk ${ }^{2}$, \\ Volodymyra Bilas ${ }^{1}$, Walery Zukow ${ }^{3 *}$
}

${ }^{1}$ OO Bohomolets' Institute of Physiology, Kyïv, Ukraine

${ }^{2}$ IY Horbachevs'kyi National Medical University, Ternopil', Ukraine

${ }^{3}$ Nicolaus Copernicus University, Torun, Poland

*w.zukow@wp.pl

\begin{abstract}
Background. Drinking mineral water is one of the ethnopharmacologic factors. Organic substances, despite their presence in all drinking mineral waters, are still considered to be active only in the water of Naftussya type (which, due to mineralization less than $1 \mathrm{~g} / \mathrm{L}$, are not formally mineral), whereas the physiological activity of true mineral waters (which mineralization is greater than 1-2 g/L) are associated with electrolytes and trace elements. Previously, we identified the role of organic carbon and nitrogen of mineral waters in their effects on certain metabolic and neuro-endocrine parameters. The purpose of this study is to clarify the role of organic substances of same mineral waters in their effects on immunity parameters. Material and methods. Experiment was performed on 48 healthy female Wistar rats 240-290 g divided into 5 groups. Animals of the first group for 6 days administered a single tap water through the tube at a dose of $1,5 \mathrm{~mL} / 100 \mathrm{~g}$ of body mass. In the second group we administered the water Naftussya from the Truskavets' layer (Galychyna, Ukraine), in the third group the water Sophiya of the Truskavets' field. The rats of the fourth group received the native water from the Hertsa (Bucovyna, Ukraine) field, and the last group received its artificial salt analogue. The day after the completion of the drinking course in all rats immunne parameters were registered. Results. On the basis of the correlation analysis with step-by-step exclusion, 9 immune parameters (Endotheliocytes of Thymus, Spleen Mass Index, Entropy of Splenocytogram, Natural Killers, B- and 0-Lymphocytes, Rod-shaped Neutrophils, Phagocytic Index and Microbian Count of Monocytes of Blood) are included in the regressive model for organic nitrogen $(R=0,818)$ and 6 parameters (Endotheliocytes of Thymus, Fibroblastes and Reticulocytes of Spleen, Pan-Lymphocytes, Microbian Count of Neutrophils and Phagocytic Index of Monocytes of Blood) for organic carbon $(\mathrm{R}=0,690)$. Together, the organic components of the chemical composition of loading fluids determine their effect on the immune parameters by $77 \%$. Conclusion. Organic substances of mineral waters play an essential role in their effects on the immune parameters of female rats.
\end{abstract}

Key words: Mineral waters, organic carbon and nitrogen, female rats, immunity. 


\section{Introduction}

Drinking mineral water is one of the ethnopharmacological factors. Back in 1975, with the chemical analysis of over 300 mineral waters of the then USSR, organic matter was discovered in all of them without exception. It is shown that for water of one type, the presence of bitumen, naphthenic acids and phenols is typical, while for other types of humic and carboxylic acids and again phenols are characteristic [1]. Despite this, it is still assumed that the physiological activity of drinking mineral waters is due to their electrolytes, the concentration of which is from 2 to $30 \mathrm{~g} / \mathrm{L}$, as well as the trace elements, while the role of organic substances is ignored, apparently because of their relatively insignificant concentration (5-40 $\mathrm{mg} / \mathrm{L}$ ). And only for Naftussya and Berezovs'ka waters (Ukraine), which are not formally mineral, because they contain less than $1 \mathrm{~g} / \mathrm{L}$ of electrolytes, organic substances are considered as active principles [2-7].

Organic compounds (in $\mathrm{mg} / \mathrm{L}$ ) of Naftussya water obtained by Solid Phase Extraction method and mass-spectroscopy has the following form. Paraffins 4,10 - 4,20; monoolefins 1,67 - 1,75; dienes and monocycloolefins 0,84 - 0,85; alkylbenzene 1,55 - 1,54; alkenylbenzene 0,47 0,46 ; esters of aromatic acids 1,32 - 1,33; alkyl phenols 1,14 - 1,14; polyaromatic hydrocarbons 0,077 - 0,059; oxygene-containing connections (acids) 1,12 - 1,14; sulfur-containing connections 0,30 - 0,31; alkylnaphthalenes 0,53 - 0,53; unidentified polyaromatic hydrocarbons 0,19 0,19 ; connections required subsquent identification $0,48-0,50$ by using as Sorbents Tenacle GC 60/80 and Polysorb-2 correspondingly [8].

As such a complete analysis is extremely labor intensive and expensive, the organic component of water is usually judged by the gross organic carbon and nitrogen content.

Previously, we have shown that drinking water with different contents of electrolytes, trace elements and organic substances has both general
[9] and different effects on the parameters of metabolism [10] and the neuroendocrine-immune complex [11] in female rats, which they have been drinking for 6 days.

In the next study, we identified the role of organic carbon and nitrogen of mineral waters in their effects on certain metabolic [12] and neuroendocrine [13] parameters.

\section{Objective}

The purpose of this study is to clarify the role of organic carbon and nitrogen of mineral waters in their effects on certain immune parameters.

\section{Methods}

Experiment was performed on 48 healthy female Wistar rats $240-290 \mathrm{~g}$ divided into 5 groups. Rats of the first (control) group for 6 days administered a single tap water through the tube at a dose of 1,5 $\mathrm{mL} / 100 \mathrm{~g}$ of body mass. In the second group was given daily drinking of animals with water Naftussya from the Truskavets' (Galychyna, Ukraine) layer, in the third group the rats were louded with the water Sophiya of the Truskavets' field. The rats of the fourth group received the native water from the Hertsa (Bucovyna, Ukraine) field, and the last - its artificial salt analogue. The chemical composition of the applied waters (according to Truskavetsian Hydrogeological Regime-Operational Station data) is given in Table 1.

The day after the completion of the drinking course in rats, at first, a sample of peripheral blood (by incision of the tip of the tail) was taken for analysis of Leukocytogram (LCG), ie the relative content of lymphocytes (L), monocytes (M), eosinophils (Eo), basophils (Bas), rod-shaped (RN) and segmental (SN) neutrophils. Based on these data, the Entropy of the Leukocytogram (hLCG) was calculated according to the formula derived by IL Popovych [14] on the basis of the classical CE Shannon formula:

hLCG

$[\mathrm{L} \cdot \log 2 \mathrm{~L}+\mathrm{M} \bullet \log 2 \mathrm{M}+\mathrm{Eo} \cdot \log 2 \mathrm{Eo}+\mathrm{Bas} \bullet \log 2 \mathrm{Bas}+\mathrm{RN} \bullet \operatorname{lo}$ $\mathrm{g} 2 \mathrm{RN}+\mathrm{SN} \cdot \log 2 \mathrm{SN}] / \log 26$.

The experiment was completed by decapitation of rats in order to collect as much blood as possible. The parameters of immunity were determined as described in the manual [15]: the relative content of the 
population of T-lymphocytes in a test of spontaneous rosette formation with erythrocytes of sheep, their theophylline-resistant and theophylline-susceptible subpopulations (by the test of sensitivity of rosette formation to theophylline); the population of Blymphocytes (by the test of complementary rosette formation with erythrocytes of sheep). Natural killers were identified as large granules contain lymphocytes. The content of 0-lymphocytes was calculated by the balance method.

About the condition of the phagocytic function of neutrophils (microphages) and monocytes (macrophages) were judged by the phagocytosis index, the microbial count and the killing index for Staphylococcus aureus (ATCC N25423 F49) $[5,7,16]$.

Immune organs weighed and made smears-imprints for counting Thymocytogram and Splenocytogram $[5,17]$. The components of the thymocytogram (TCG) are lymphocytes $(\mathrm{Lc})$, lymphoblasts $(\mathrm{Lb})$, reticulocytes (R), macrophages (Mac), endotheliocytes (En), epitheliocytes (Ep) and Hassal's corpuscles (Has). The Splenocytogram (SCG) includes lymphocytes (Lc), lymphoblasts (Lb), plasma cells $(\mathrm{P})$, reticulocytes $(\mathrm{R})$, macrophages $(\mathrm{Ma})$, fibroblasts $(\mathrm{F})$, microphages $(\mathrm{Mi})$ and eosinophils (E).

For them CE Shannon's entropy was calculated too by using formulas $[17,18]$ :

hTCG

$[\mathrm{Lc} \bullet \log 2 \mathrm{Lc}+\mathrm{Lb} \bullet \log 2 \mathrm{Lb}+\mathrm{R} \bullet \log 2 \mathrm{R}+\mathrm{Mac} \bullet \log 2 \mathrm{Mac}+\mathrm{En} \bullet 1$ og2En+Ep•log2Ep+Has $\bullet \log 2 \mathrm{Has}] / \log 27$

$\mathrm{hSCG}$ $=$

$[\mathrm{Lc} \bullet \log 2 \mathrm{Lc}+\mathrm{Lb} \bullet \log 2 \mathrm{Lb}+\mathrm{P} \bullet \log 2 \mathrm{P}+\mathrm{R} \bullet \log 2 \mathrm{R}+\mathrm{Ma} \bullet \log 2 \mathrm{M}$ $\mathrm{a}+\mathrm{F} \bullet \log 2 \mathrm{~F}+\mathrm{Mi} \bullet \log 2 \mathrm{Mi}+\mathrm{E} \cdot \log 2 \mathrm{E}] / \log 28$

Digital material is statistically processed on a computer using the software package "Statistica 64".

\section{Results}

The calculations by the formula:

$|r| \geq\{\exp [2 t /(n-1,5) 0,5]-1\} /\{\exp [2 t /(n-1,5) 0,5]$

$+1\}$,

showed that for a sample of 48 animals, the critical value of the modulus of the correlation coefficient $|r|$ for $p<0,05(t>2,0)$ is 0,28 , for $p<0,01$ $(\mathrm{t}>2,7)$ is 0,38 , for $\mathrm{p}<0,001(\mathrm{t}>3,5)$ is 0,48 .
First of all it was found that there is no correlation between the content in liquids of organic carbon and nitrogen $(\mathrm{r}=-0,12)$. Therefore, they represent different groups of organic substances.

At the next stage, regression models were created by stepwise exclusion to reach the maximum value of Adjusted R2. It was stated (Table 2) that organic nitrogen causes an increase in the relative content of natural killers and B-lymphocytes (accompanied by a decrease in 0-lymphocytes), as well as rod-shaped neutrophils. Organic nitrogen acts on the microbial number of monocytes by the type of upregulation, while on their phagocytic activity - by the type of downregulation. In addition, this chemical factor causes an increase in spleen mass and entropy of the splenocytogram, adversely affecting the content of endothelial cells in the thymocytogram. The degree of determination by organic nitrogen of this immune constellation is $67 \%$.

The objects of regulatory influence of organic carbon, common to those of organic nitrogen, are the phagocytic index of blood monocytes and thymic endotheliocytes. The effect on the first parameter is the same suppressive, while on the second - activating. Maximum upregulation was detected relative to the intensity of neutrophil phagocytosis, whereas levels of pan-lymphocytes in the blood and fibroblasts and reticulocytes in the spleen are subject to downregulation. The degree of determination by organic carbon of this immune constellation is $48 \%$ (Table 3).

As a result of canonical analysis, two pairs of roots were identified. The chemical root of the first pair is represented to the maximum extent by organic nitrogen, while organic carbon gives a much smaller and opposite sign load factor (Table 4).

The immune root is represented by parameters that are subordinate to the upregulation (NK- and Blymphocytes, rod-chaped neutrophils, intensity of monocyte phagocytosis, spleen mass and splenocytogram entropy) or downregulation (0lymphocytes of blood, endothelial cells of the thymus and activity of monocyte phagocytosis) by organic nitrogen, as well as to the activation (intensity of neutrophil phagocytosis) or suppression (reticulocytes and fibroblasts of the spleen and blood lymphocytes level) by organic carbon. The degree of determination of organic matter of this immune constellation reaches $77 \%$ (Fig. 1).

The chemical root of the second pair is maximally represented by organic carbon while organic nitrogen gives a much smaller but 
unidirectional factor load. The immune root is represented mainly by the parameters subject to the suppressive effect of organic carbon (blood lymphocytes, splenic reticulocytes and fibroblasts and the activity of phagocytosis of monocytes) or nitrogen (intensity of phagocytosis of monocytes), as well as those activated by carbon (thymus endothelial cells and the intensity of neutrophil phagocytosis) or nitrogen (blood rod-shaped neutrophils and spleen mass) (Table 5). However, the determining effect of organic substances on such an immune constellation is much weaker - only $43 \%$ (Fig. 2).

\section{Discussion}

The results of this study, in our opinion, prove the significant role of organic substances in drinking mineral waters in their immunomodulatory action. We assume that the following groups of compounds are immunomodulators: alkylbenzene, alkenylbenzene, esters of aromatic acids, alkyl phenols, polyaromatic hydrocarbons, alkylnaphthalenes, unidentified polyaromatic hydrocarbons, the share of which in the total mass is $38 \%$, therefore, the intake of substances in the body is about $7,9 \mu \mathrm{g} / \mathrm{kg} \bullet$ day.

This assumption is based on the fact that cells within the immune system, such as lymphocytes (T cells and B cells), macrophages, dendritic cells, granulocytes, and natural killer cells express aryl hydrocarbon receptor (AhR). The expression of the AhR in a majority of immune cell types and the expression of multiple xenobiotic- or dioxin-responsive elements (XREs/DREs) in the promoter region of many genes that regulate the immune response demonstrates the importance of this receptor in immunological processes [reviews: 19-21]. The most interesting feature of AhR ligands is their ability to induce the alteration M1/M2 macrophage polarization $[22,23]$ as well as the differentiation of T-regulatory vs Th-17 cells [reviews: $24,25]$.

Researchers have discovered a wide range of AhR ligands, both natural and synthetic, including environmental contaminants, dietary compounds, microbial byproducts, and endogenous mediators. Typically components of environmental pollutants: polycyclic aromatic hydrocarbons such as benzo(a)pyrene, anthracene, and 3-methylcholanthrene as well as halogenated aromatic hydrocarbons such as polychlorinated dibenzo-p-dioxins, dibenzofurans, and biphenyls [review: 26].
As we can see, the presence of AhR ligands is quite probable in the constellation of organic substances found in the waters.

The AhR was first discovered in the early 1970s for its ability to bind 2,3,7,8-Tetrachlorodibenzo-p-dioxin with high affinity and induce a xenobioticmetabolizing enzyme known as aryl hydrocarbon hydroxylase. Initially, the AhR was thought to be involved predominantly in the metabolism of environmental chemicals. Researchers discovered a mechanism by which the AhR can direct the metabolism of xenobiotics by increasing the levels of cytochrome P450 enzymes, which then causes biotransformation and increases the water solubility of foreign chemicals, which leads to their expulsion [review: 26].

Back in 1990, we found in an experiment that both native Naftussya water and the organic substances isolated from it reduce the duration of nembutal sleep $[27,28]$, which indicates the induction of hydroxylases.

Recently, in clinical observation, we found that course drinking of stable water solution of the Ozokerite, extracted from the Boryslav's field, imitates favorable effects of Naftussya water on parameters of immune and autonomous nervous systems at volunteers with their dysfunction [29-31].

In conclusion, we consider it appropriate to recall the results of our studies on the same rats published earlier. On the basis of the correlation analysis with step-by-step exclusion, four metabolites of blood as well as five metabolites of urine are included in the regressive model for organic carbon $(\mathrm{R}=0,697$; $\mathrm{R} 2=0,486 ; \quad$ Adjusted $\mathrm{R} 2=0,347 ; \quad \mathrm{F}(10,4)=3,5$; $p=0,0025)$. Organic nitrogen of mineral waters affects five metabolic parameters of urine only, but with approximately the same force $(\mathrm{R}=0,621 ; \mathrm{R} 2=0,385$; Adjusted R2=0,312; $F(5,4)=5,3 ; p=0,0008)$ [12]. Four endocrine parameters are included in the regressive model for organic nitrogen $(\mathrm{R}=0,543 ; \mathrm{R} 2=0,295$; Adjusted R2 $=0,229 ; \mathrm{F}(4,4)=4,5 ; \mathrm{p}=0,004)$ and three parameters for organic carbon $(\mathrm{R}=0,407 ; \mathrm{R} 2=0,165$; Adjusted R2 $=0,109 ; \mathrm{F}(3,4)=2,9 ; \mathrm{p}=0,045)$. Together, the organic components of the chemical composition of loading fluids determine their effect on the endocrine parameters by $39 \%$ [13].

\section{Conclusion}

Taken together, these results indicate that the organic matter of mineral waters has a modulating 
effect on the parameters of the autonomic nervous, endocrine and immune systems, which are known to interact closely within the triune neuro-endocrineimmune complex [7,32-35].

\section{Conformity to ethical standards}

Experiments on animals have been carried out in accordance with the provisions of the Helsinki Declaration of 1975, revised and supplemented in 2002 by the Directives of the National Committees for Ethics in Scientific Research.

The carrying out of experiments was approved by the Ethics Committee of the Horbachevs'kyi Ternopil' National Medical University. The modern rules for the maintenance and use of laboratory animals complying with the principles of the European Convention for the Protection of Vertebrate Animals used for scientific experiments and needs are observed (Strasbourg, 1985).

Conflict of interest. The authors declare that they have no conflict of interest.

\section{References}

1.Tsarfis, P.G., Danilova, Yu.Ye. (1975). Basic Principles of Treatment for Patients at the Resorts of the USSR. Moskva. Meditsina; 312. [In Russian].

2.Yaremenko, M.S., Ivassivka, S.V., Popovych, I.L., Bilas, V.R., Yasevych, A.P., Zahorodnyuk, V.P. et al. (1989). Physiological Bases of Curative Effect of Water Naftussya. Kyiv. Naukova dumka; 144. [in Russian].

3.Ivassivka, S.V. (1997). Biological Active Substances of Water Naftussya, their Genesis and Mechanisms of Physiological Effects. Kyiv. Naukova dumka; 110. [in Ukrainian].

4.Ivassivka, S.V., Popovych, I.L., Aksentijchuk, B.I., Bilas, V.R. (1999). Nature of Balneofactors of Water Naftussya and Essence its Curative and Prophilactive Effects. Truskavets'. Truskavets'kurort; 125. [in Ukrainian].

5.Bilas, V.R., Popovych, I.L. (2009). Role of microflora and organic substances of water Naftussya in its modulating influence on neuroendocrine-immune complex and metabolism. Medical Hydrology and Rehabilitation. 7(1): 68-102. [in Ukrainian].

6.Popovych, I.L., Ivassivka, S.V. (2009). Role of organic substances of water Naftussya in its physiological activity. Medical Hydrology and Rehabilitation, 7(2): 6-26. [in Ukrainian].

7.Popovych, I.L. (2011). Stresslimiting Adaptogene Mechanism of Biological and Curative Activity of Water Naftussya. Kyiv. Computerpress; 300. [in Ukrainian].

8.Dats'ko, O.R., Bubnyak. A.B., Ivassivka, S.V. (2008). The organic part in mineral water Naftussya. Development of knowledges about its composition and origination. Medical Hydrology and Rehabilitation, 6(1): 168-174. [in Ukrainian].

9.Zavidnyuk, Y.V., Mysula, I.R., Klishch, I.M., Zukow, W., Popovych, I.L., Korda, M.M. (2018). General nonspecific metabolic, neuroendocrine and immune reactions to various water-salt loads in female rats. Journal of Education, Health and Sport, 8(3): 513-524. 10.Gozhenko, A.I., Zavidnyuk, Y.V., Sydliaruk, N.I., Mysula, I.R., Klishch, I.M., Zukow, W. Et al. (2018). Features of metabolic reactions to various water-salt loads in female rats. Journal of Education, Health and Sport, 8(4): 496-518.

11.Gozhenko, O.A., Zavidnyuk, Y.V., Korda, M.M., Mysula, I.R., Klishch, I.M., Zukow, W., Popovych, I.L. (2018). Features of neuro-endocrine and immune reactions to various water-salt loads in female rats. Journal of Education, Health and Sport, 8(9): 11-31.

12.Popovych, I.L., Zavidnyuk, Y.V., Korda, M.M., Mysula, I.R., Klishch, I.M., Zukow, W. (2018). Role of organic carbon and nitrogen of mineral waters in their metabolic effects at female rats. Journal of Education, Health and Sport, 8(12): 793-802.

13.Zukow, W., Gozhenko, O.A., Zavidnyuk, Y.V., Korda, M.M., Mysula, I.R., Klishch, I.M. et al. (2020). Role of organic carbon and nitrogen of mineral waters in their neuro-endocrine effects at female rats. International J of Applied Exercise Physiology, 9(4): 20-25.

14.Popovych, I.L. (2007). Information effects of bioactive water Naftyssya in rats: modulation entropic, prevention desynchronizing and limitation of disharmonizing actions water immersion stress for information components of neuro-endocrine-immune system and metabolism, which correlates with gastroprotective effect. Medical Hydrology and Rehabilitation, 5(3): 50-70. [in Ukrainian].

15.Perederiy, V.G., Zemskov, A.M., Bychkova, N.G., Zemskov, V.M. (1995). Immune status, principles of its evaluation and correction of immune disorders. Kyiv. Zdorovya; 211. [in Russian].

16.Douglas, S.D., Quie, P.G. (1981). Investigation of Phagocytes in Disease. Churchil. 110. 
17.Bilas, V.R., Popadynets', O.O., Flyunt, I-S.S., Sydoruk, N.O., Badiuk, N.S., Gushcha, S.G. et al. (2020). Entropies of thymocytogram, splenocytogram, immunocytogram and leukocytogram in rats are regulated by sex and the neuroendocrine parameters while regulates immune parameters. Journal of Education, Health and Sport, 10(7): 266-288.

18.Popadynets', O., Gozhenko, A., Badyuk, N., Popovych, I., Skaliy, A., Hagner-Derengowska, M. et al (2020). Interpersonal differences caused by adaptogen changes in entropies of EEG, HRV, immunocytogram, and leukocytogram. Journal of Physical Education and Sport, 20(Supp1 2), 982-999.

19.Quintana, F.J., Sherr, D.H. (2013). Aryl hydrocarbon receptor control of adaptive immunity. Pharmacol Rev, 65(4): 1148-1161.

20.Esser, C., Rannug, A. (2015). The aryl hydrocarbon receptor in barrier organ physiology, immunology, and toxicology. Pharmacol Rev, 67(2): 259-279.

21.Avilla, M.N., Malecki, K.M.C., Hahn, M.E., Wilson, R.H., Bradfield, C.A. (2020). The Ah Receptor: Adaptive Metabolism, Ligand Diversity, and the Xenokine Model. Chem Res Toxicol, 33(4): 860-879.

22.Climaco-Arvizu, S., Domínguez-Acosta, O., Cabañas-Cortés, M.A., et al. (2016). Aryl hydrocarbon receptor influences nitric oxide and arginine production and alters M1/M2 macrophage polarization. Life Sci, 155: 76-84.

23.Yang, X., Liu, H., Ye, T., Duan, C., Lv, P., Wu, X. et al (2020). AhR activation attenuates calcium oxalate nephrocalcinosis by diminishing M1 macrophage polarization and promoting M2 macrophage polarization. Theranostics, 10(26), 12011-12025.

24.Prasad Singh, N., Nagarkatti, M., Nagarkatti, P. (2020). From Suppressor T cells to Regulatory T cells: How the Journey That Began with the Discovery of the Toxic Effects of TCDD Led to Better Understanding of the Role of AhR in Immunoregulation. International journal of molecular sciences, 21(21), 7849.

25.Abdulla, O. A., Neamah, W., Sultan, M., Chatterjee, S., Singh, N., Nagarkatti, M., Nagarkatti, P. (2021). AhR Ligands Differentially Regulate miRNA-132 Which Targets HMGB1 and to Control the Differentiation of Tregs and Th-17 Cells During Delayed-Type Hypersensitivity Response. Frontiers in immunology, 12, 635903.
26.Busbee, P. B., Rouse, M., Nagarkatti, M., Nagarkatti, P. S. (2013). Use of natural AhR ligands as potential therapeutic modalities against inflammatory disorders. Nutrition reviews, 71(6), 353-369.

27.Ivassivka, S.V., Popovych, I.L., Yaremenko, M.S., Kovbasnyuk, M.M. (1990). Mineral water Naftussya as xenobiotic. Fiziol Zhurn, 36(3): 40-45. [in Russian].

28.Popovych, I.L., Ivassivka, S.V., Yasevych, A.P., Havdyak, M.V., Bilyk, I.I. (1990). Protective effect of organic substances of water naftussya on erosiveulcerative lesions of the gastric mucosa in rats under immobilization-cold stress. Fiziol Zhurn, 36(4): 68-76. [in Russian].

29.Popovych, I.L., Gumega, M.D., Verba, I.E., Popovych, A.I., Korolyshyn, T.A., Tkachuk, S.P. et al. (2016). Comparative investigation effects on nervous and immune systems of bioactive water Naftussya spa Truskavets' and stable water solution of Boryslav's ozokerite. Journal of Education, Health and Sport, 6(4): 364-374.

30.Popovych, A.I. (2018). Features of the immunotropic effects of partial components of the balneotherapeutic complex of spa Truskavets'. Journal of Education, Health and Sport, 8(12): 919-935.

31.Popovych, A.I. (2019). Features of the neurotropic effects of partial components of the balneotherapeutic complex of spa Truskavets'. Journal of Education, Health and Sport, 9(1): 396-409.

32.Thayer, J.F., Sternberg, E.M. (2010). Neural aspects of immunomodulation: Focus on the vagus nerve. Brain Behav Immun, 24(8): 1223-1228.

33.Chavan, S.S., Pavlov, V.A., Tracey, K.J. (2017). Mechanism and therapeutic relevance of neuroimmune communication. Immunity, 46: 927-942.

34.Chavan, S.S., Tracey, K.J. (2017). Essencial Neuroscience in Immunology. J Immunol, 198: 33893397.

35.Pavlov, V.A., Chavan, S.S., Tracey, K.J. (2018). Molecular and functional neuroscience in immunity. Annu Rev Immunol, 36: 783-812.

36.Popovych, I.L., Gozhenko, A.I., Zukow, W., Polovynko, I.S. (2020). Variety of Immune Responses to Chronic Stress and their Neuro-Endocrine Accompaniment. Scholars' Press. Riga; 172. 
Table 1. The chemical composition of the applied mineral waters

\begin{tabular}{|c|c|c|c|c|c|}
\hline & Tap Water & Sofiya & Hertsa & Salt analogue & Naftussya \\
\hline \multicolumn{6}{|c|}{ Electrolytes, $\mathrm{mM} / \mathrm{L}$} \\
\hline $\mathrm{Na}^{+}$ & 0,5 & 156 & 196,7 & 196,7 & 0,6 \\
\hline $\mathrm{Cl}^{-}$ & 3,4 & 142 & 205 & 205 & 1,0 \\
\hline $\mathrm{HCO}_{3}^{-}$ & 2,9 & 7,5 & 5,6 & 5,6 & 8,2 \\
\hline $\mathrm{Ca}^{2+}$ & 3,4 & 5,3 & 3,40 & 3,40 & 2,9 \\
\hline $\mathrm{Mg}^{2+}$ & 0,5 & 4,3 & 3,44 & 3,44 & 2,3 \\
\hline $\mathrm{K}^{+}$ & 0,4 & 0,3 & 0,4 & 0,4 & 0,3 \\
\hline $\mathrm{SO}_{4}{ }^{2-}$ & 1,2 & 13,1 & 0,1 & 0,1 & 1,0 \\
\hline \multicolumn{6}{|c|}{ Trace elementes, $\mathrm{mg} / \mathrm{L}$} \\
\hline $\mathrm{H}_{2} \mathrm{SiO}_{3}$ & 5 & 4,43 & 9,88 & 0 & 9,5 \\
\hline $\mathrm{H}_{3} \mathrm{BO}_{3}$ & 0,25 & 8,39 & 42,76 & 0 & 0,200 \\
\hline $\mathrm{Br}$ & 8,3 & 6,7 & 21,17 & 0 & 0,034 \\
\hline $\mathrm{J}$ & 0,025 & 1,29 & 6,62 & 0 & 0,004 \\
\hline $\mathrm{F}$ & 0,95 & 0,52 & 0,57 & 0 & 0,160 \\
\hline \multicolumn{6}{|c|}{ Organic substances, mg/L } \\
\hline C org & 5,0 & 5,5 & 34 & 0 & 13,8 \\
\hline $\mathrm{N}$ org & 0,02 & 0,8 & 0,14 & 0 & 0,33 \\
\hline
\end{tabular}

Table 2. The result of regression analysis with step-by-step exclusion of immune parameters in relation to the content of organic nitrogen in liquids

\begin{tabular}{|c|c|c|c|c|c|c|c|}
\hline $\begin{array}{l}\text { Nitrogen Organic }(\mathrm{mg} / \mathrm{L}) \\
\text { as Independent Variable }\end{array}$ & & Beta & $\begin{array}{l}\text { St. Err. } \\
\text { of Beta }\end{array}$ & $\mathrm{B}$ & $\begin{array}{l}\text { St. Err. } \\
\text { of B }\end{array}$ & $t_{(38)}$ & $\begin{array}{l}\text { p- } \\
\text { level }\end{array}$ \\
\hline Dependent Variables & $\mathrm{r}$ & & Intercpt & $-5,734$ & 1,253 & $-4,58$ & $10^{-4}$ \\
\hline Natural Killer Lymphocytes, \% & 0,44 & ,533 &, 120 & 0782 &, 0176 & 4,45 & $10^{-4}$ \\
\hline Stub Neutrophils of Blood, \% & $\mathbf{0 , 3 4}$ & 227 &, 102 &, 0585 &, 0262 & 2,23 &, 032 \\
\hline Microbian Count of Monocytes, $\mathrm{B} / \mathrm{Ph}$ & $\mathbf{0 , 3 0}$ & 277 &, 121 & 0437 & 0191 & 2,29 &, 027 \\
\hline B-Lymphocytes, \% & 0,25 &, 775 &, 187 &, 0724 &, 0174 & 4,16 & $10^{-3}$ \\
\hline Spleen Mass Index, mg/100 g BM & 0,21 &, 236 & , 103 & 1,1962 & ,5199 & 2,30 &, 027 \\
\hline Entropy of Splenocytogram & 0,21 & 292 &, 105 & 4,8910 & 1,7565 & 2,78 &, 008 \\
\hline 0-Lymphocytes, \% & $-0,26$ & ,494 & ,191 & 0193 & 0075 & 2,58 &, 014 \\
\hline Endotheliocytes of Thymus, \% & $-0,18$ &,- 255 &, 114 &,- 0802 & 0359 & $-2,23$ &, 031 \\
\hline Phagocytic Index of Monocytes, \% & $-0,16$ &,- 327 &, 110 &,- 1104 & ,0369 & $-2,99$ &, 005 \\
\hline & \multicolumn{7}{|c|}{$R=0,818 ; R^{2}=0,669 ;$ Adjusted $R^{2}=0,591 ; F_{(9,4)}=8,5 ; p<10^{-5}$} \\
\hline
\end{tabular}

Table 3. The result of regression analysis with step-by-step exclusion of immune parameters in relation to the content of organic carbon in liquids

\begin{tabular}{|l|l|l|l|l|l|l|l|}
\hline $\begin{array}{l}\text { Carbogen Organic (mg/L) } \\
\text { as Independent Variable }\end{array}$ & & Beta & $\begin{array}{l}\text { St. Err. } \\
\text { of Beta }\end{array}$ & B & $\begin{array}{l}\text { St. Err. } \\
\text { of B }\end{array}$ & $\mathrm{t}_{(41)}$ & $\begin{array}{l}\mathrm{p}- \\
\text { level }\end{array}$ \\
\hline Dependent Variables & $\mathrm{r}$ & & Intercpt & 79,02 & 24,27 & 3,26 &, 002 \\
\hline Microbian Count of Neutrophils, B/Ph & $\mathbf{0 , 3 9}$ &, 243 &, 126 & 2,596 & 1,350 & 1,92 &, 061 \\
\hline Endotheliocytes of Thymus, \% & 0,23 &, 229 &, 119 & 3,010 & 1,569 & 1,92 &, 062 \\
\hline Lymphocytes of Blood, \% & $\mathbf{- 0 , 3 1}$ &,- 437 &, 116 &,- 749 &, 198 & $-3,78$ & $10^{-3}$ \\
\hline Fibroblastes of Spleen, \% & $\mathbf{- 0 , 3 1}$ &,- 289 &, 122 & $-2,184$ &, 922 & $-2,37$ &, 023 \\
\hline Reticulocytes of Spleen, \% & $\mathbf{- 0 , 2 8}$ &,- 230 &, 117 & $-1,674$ &, 852 & $-1,97$ &, 056 \\
\hline Phagocytic Index of Monocytes, \% & $-0,26$ &,- 155 &, 115 & $-2,184$ & 1,619 & $-1,35$ &, 185 \\
\hline & $\mathbf{R}=\mathbf{0 , 6 9 0} ; \mathbf{R}^{\mathbf{2}}=\mathbf{0 , 4 7 7}$;djusted $\mathbf{R}^{2}=\mathbf{0 , 4 0 0} ; \mathbf{F}_{(\mathbf{6}, 4)}=\mathbf{6 , 2} ; \mathbf{p}=\mathbf{0 , 0 0 0 1}$ \\
\hline
\end{tabular}


Table 4. Factor structure of the first pair of canonical roots, which represent the content in liquids of organic nitrogen and carbon and immune parameters

\begin{tabular}{|l|l|}
\hline \multicolumn{1}{|c|}{ Chemic factors } & Root 1 \\
\hline Nitrogen Organic (mg/L) & $\mathbf{8 7 6}$ \\
\hline Carbon Organic (mg/L) &,- 588 \\
\hline \multicolumn{1}{|c|}{ Immune parameters } & Root 1 \\
\hline Natural Killer Lymphocytes, \% & $\mathbf{, 5 8 3}$ \\
\hline Microbian Count of Monocytes, B/Ph & $\mathbf{, 4 4 1}$ \\
\hline B-Lymphocytes, \% & $\mathbf{3 1 4}$ \\
\hline Stub Neutrophils of Blood, \% & $\mathbf{2 9 2}$ \\
\hline Entropy of Splenocytogram & $\mathbf{2 4 9}$ \\
\hline Spleen Mass Index, mg/100 g BM & $\mathbf{, 1 6 3}$ \\
\hline 0-Lymphocytes, \% &,- 351 \\
\hline Endotheliocytes of Thymus, \% &,- 296 \\
\hline Microbian Count of Neutrophils, B/Ph &,- 691 \\
\hline Reticulocytes of Spleen, \% &, 334 \\
\hline Fibroblastes of Spleen, \% &, 315 \\
\hline
\end{tabular}

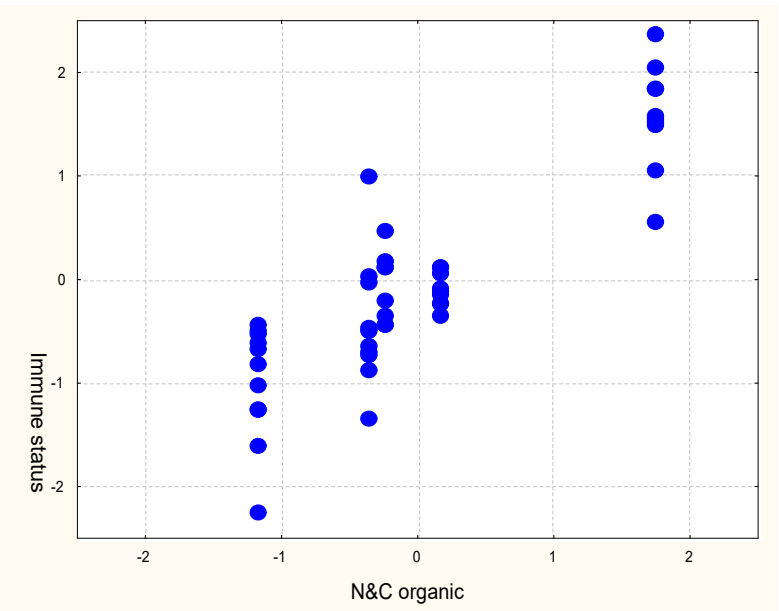

$\mathrm{R}=0,878 ; \mathrm{R}^{2}=0,772 ; \chi^{2}(26)=80 ; \mathrm{p}<10^{-6} ; \Lambda$ Prime $=0,130$

Fig. 1. Scatterplot of canonical correlation between the first pair of roots, which represent the content in liquids of organic nitrogen and carbon ( $\mathrm{X}$-axis) and immunity parameters (Y-axis)

Table 5. Factor structure of the second pair of canonical roots, which represent the content in liquids of organic nitrogen and carbon and immune parameters

\begin{tabular}{|l|l|}
\hline \multicolumn{1}{|c|}{ Chemic factors } & Root 2 \\
\hline Carbon Organic (mg/L) &,- 809 \\
\hline Nitrogen Organic (mg/L) &,- 483 \\
\hline \multicolumn{1}{|c|}{ Immune parameters } & Root 2 \\
\hline Lymphocytes of Blood, \% &, 548 \\
\hline Phagocytic Index of Monocytes, \% &, 488 \\
\hline Fibroblastes of Spleen, \% &, 272 \\
\hline Reticulocytes of Spleen, \% &, 208 \\
\hline Endotheliocytes of Thymus, \% &,- 138 \\
\hline Microbian Count of Neutrophils, B/Ph &,- 063 \\
\hline Stub Neutrophils of Blood, \% &,- 369 \\
\hline Spleen Mass Index, mg/100 g BM &,- 257 \\
\hline Microbian Count of Monocytes, B/Ph &, 138 \\
\hline
\end{tabular}




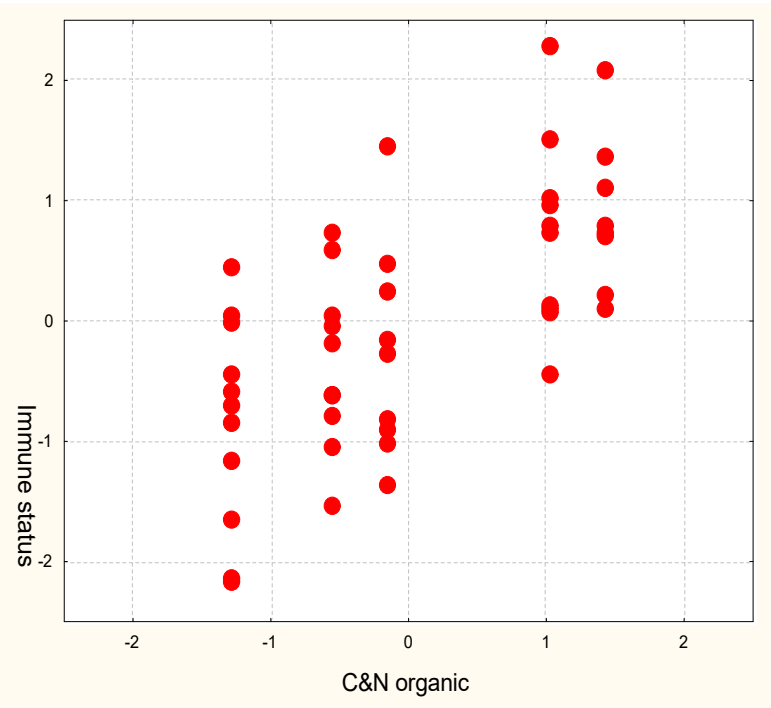

$\mathrm{R}=0,657 ; \mathrm{R}^{2}=0,431 ; \chi^{2}{ }_{(12)}=22 ; p=0,037 ; \Lambda$ Prime $=0,569$

Fig. 2. Scatterplot of canonical correlation between the second pair of roots, which represent the content in liquids of organic nitrogen and carbon ( $\mathrm{X}$-axis) and immunity parameters (Y-axis) 